\begin{abstract}
특발두개내압상숭의 Magnetic Resonance Imaging 징후

김고운 ${ }^{a, b}$ 신현준 ${ }^{a b}$

전북대학교 의과대학 전북대학교병원 신경과 ${ }^{a}$, 전북대학교 임상의학연구소 전북대학교병원 의생명연구원
\end{abstract}

\title{
Magnetic Resonance Imaging Signs, as a Dandy Compass Pointing to Idiopathic Intracranial Hypertension
}

Ko Woon Kim, MD, PhD ${ }^{a, b}$, Hyun-June Shin, MD ${ }^{a, b}$

Department of Neurology, Jeonbuk National University Hospital, Jeonbuk National University Medical School, Jeonju, Korea $^{a}$

Research Institute of Clinical Medicine of Jeonbuk National University-Biomedical Research Institute of Jeonbuk National University Hospital, Jeonju, Korea ${ }^{b}$

J Korean Neurol Assoc 38(3):239-240, 2020

19세 여자가 시야흐림과 두통으로 안과를 방문하였다. 안저검사 에서 양안 시신경유두부종이 있었고, 뇌 magnetic resonance imaging (MRI)에서 구조적 뇌병터와 수두증은 없었다. 고용량 스 테로이드 치료 후 시야흐림은 호전되었으나 두통이 지속되어 신경 과에 의뢰되었다. 신경계진찰에서 국소신경학적 결손은 없었고, 신 체비만지수가 27.4였다(키 $162 \mathrm{~cm}$, 몸무게 $72 \mathrm{~kg})$. 초기 뇌 MRI를 재검토한 결과, 안구 후면의 편평화와 부분빈안장(partial empty sella)이 보였다(Fig.). 뇌척수액검사에서 정상 뇌척수액 구성과 두 개내압 $>300 \mathrm{mmH}_{2} \mathrm{O}$ 로 특발두개내압상승으로 진단하였다. 특발 두개내압상승의 영상 징후는 안구 후면의 편평화, 시신경집(optic nerve sheath) 팽창, 시신경 비틀림, 부분빈안장이 있다. ${ }^{1,2}$ 개개의
징후는 특발두개내압상승 진단기준을 대체할 수 없고 민감도가 낮 은 제한이 있지만, 진단 접근의 맥락에서 훌륭한 지침으로 활용할 수 있다.

\section{REFERENCES}

1. Friedman DI, Jacobson DM. Diagnostic criteria for idiopathic intracranial hypertension. Neurology 2002;59:1492-1495.

2. Degnan AJ, Levy LM. Pseudotumor cerebri: brief review of clinical syndrome and imaging findings. AJNR Am J Neuroradiol 2011;32: 1986-1893.
Received December 23, 2019 Revised April 7, 2020

Accepted April 7, 2020

Address for comespondence: Hyun-June Shin, MD

Department of Neurology, Jeonbuk National University Hospital, 20

Geonji-ro, Deokjin-gu, Jeonju 54907, Korea

Tel: +82-63-250-1590 Fax: +82-63-251-9363

E-mail: thetorne@hanmail.net 

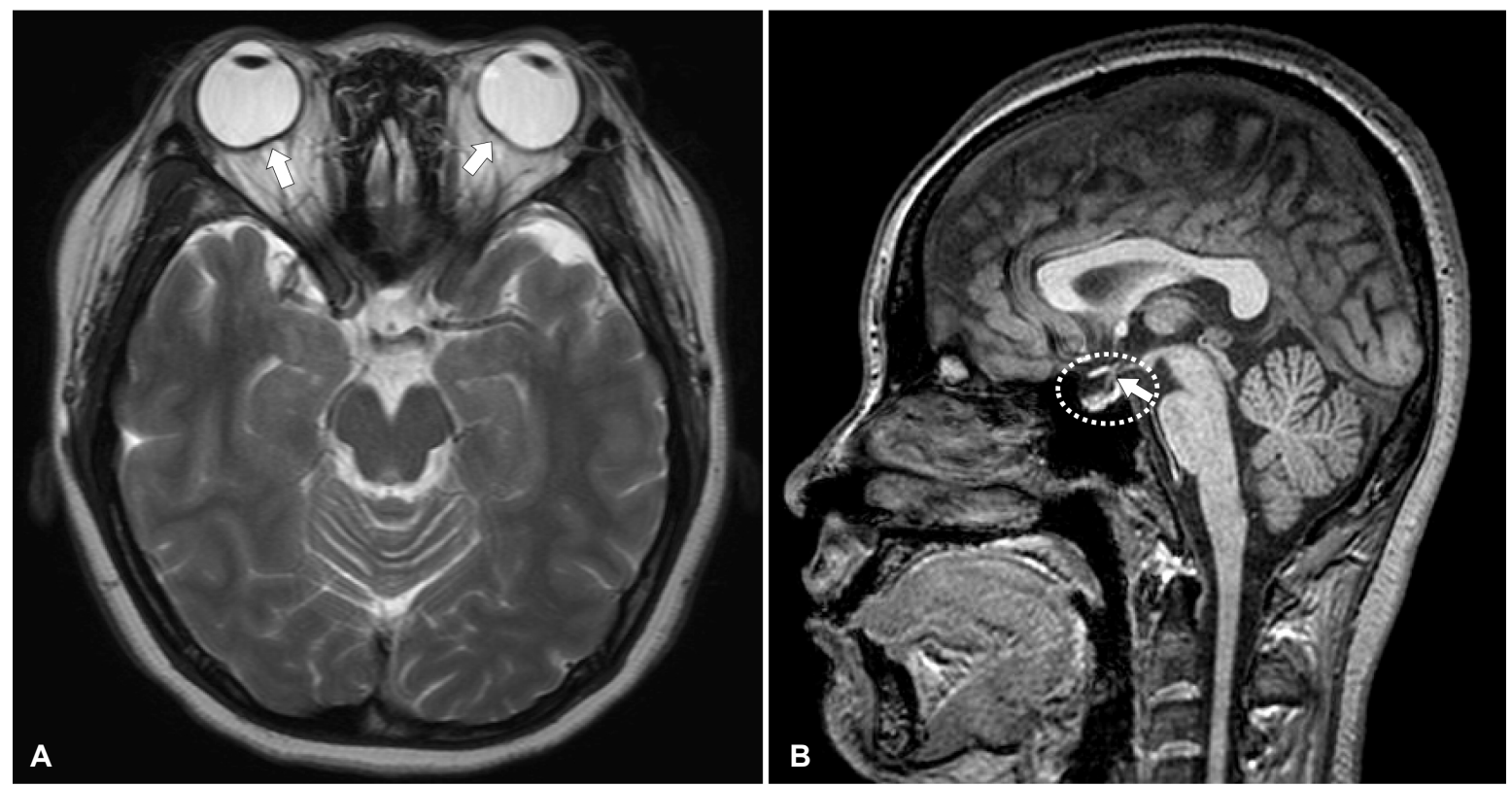

Figure. Magnetic resonance imaging (MRI) signs pointing to idiopathic intracranial hypertension. (A) Axial T2 weighted image shows posterior flattening of bilateral optic globes (arrows). (B) Sagittal T1 weighted image shows partially empty sella (dotted oval) with infundibulum sign (arrow). 